\title{
LOW VOLTAGE RELAY CONTACT RESISTANCE CHANGE INFLUENCE BY SHORT-CIRCUIT CURRENT
}

\section{ZMIANA REZYSTANCJI ZESTYKOWEJ PRZEKAŹNIKÓW NISKIEGO NAPIĘCIA POD WPŁYWEM DZIAŁANIA PRĄDÓW ZWARCIOWYCH*}

\begin{abstract}
Electromagnetic relays are exposed to switching phenomena during its service life. These phenomena may include making of a short circuit, resulting in current flow of significant value for the relay contacts. This current influences the contacts surface and thus the value of the contact resistance, which is an important exploitation parameter for electromagnetic relays. The aim of the study is to analyze the impact of current flow of substantial value on the electric contact resistance of the relay contacts. Significant changes in the resistance after each switching cycle is observed.
\end{abstract}

Keywords: relays, contact materials, contact resistance.

\begin{abstract}
Przekaźniki elektromagnetyczne w trakcie swojej eksploatacji sa narażone na niekorzystne zjawiska taczeniowe. Do narażeń tych można zaliczyć m.in. załączenie obwodu zwartego, co skutkuje przeptywem prądu o znacznej wartości przez styki przekaźnika. Przeptyw tego pradu, któremu w początkowej fazie może także towarzyszyć tuk elektryczny, wpływa na stan powierzchni styczek, a tym samym na wartość rezystancji zestykowej, będacej istotnym parametrem eksploatacyjnym przekaźników. Celem pracy jest analiza oddziaływania procesów załączania prądu o znacznej wartości na rezystancję zestykowa przekaźników. Obserwowane sa znaczne zmiany tej rezystancji po każdym cyklu łaczeniowym.
\end{abstract}

Stowa kluczowe: przekaźniki, materiały stykowe, rezystancja zestykowa

\section{Introduction}

Electromagnetic relays are commonly used to connect circuitry with moderate values of the switching current (i. e. the medium current circuits) at a voltage not exceeding $1000 \mathrm{~V}$. They are used inter alia as actuators in the building automation systems (eg. KNX, LCN, LonWorks) or in drivers and the programmable relays (Easy, NEED). They differ among themselves with a structure, purpose, and technical parameters. In regard to the contacts of connectors made of different materials, in literature, there are often presented results of research carried out as well in normal operation as in terms of specific exposures. These studies, however, are often focused on the low voltage $(<50 \mathrm{~V})$ direct current circuits [8]. Similar research were performed by Morin [16], Neuhaus [17] or Doublet [6], who independently conducted similar work for contacting materials for low voltage direct current circuits. Research related to processes of switching in circuits of medium voltage alternating current are focused on current ranges from a few to several kA [1,9]. A noticeable is the lack of research in the field of low- and medium current AC switches at currents close to normal and short-circuit working conditions which may occur in low voltage electrical installations, that usually do not exceed $1 \mathrm{kA}$. Within the scope of modeling simulation studies are being conducted on the heating rail and contact connections with complex shapes, configurations and utilizing a variety of conductive materials [10].

Relays for connecting the receiving circuits are exposed to unfavorable processes. These phenomena may include closing overload and short-circuit currents, which may lead to shortening the life ofrelays or, in extreme cases, their total damage. The article describes the impact of switching short-circuit on the change of the contact re- sistance. Relays with three different contacting materials have been investigated.

Contact resistance of the connector is the important performance parameter. It is important that during the utilisation of the relay this resistance reaches values as small as possible and simultaneously do not differed significantly in time. Among other things, associated with its heating the safe working load of the relay depends on its value [15]. The contact resistance value is dependent on [7, 14]:

- shape resistance $R_{k}$,

- tarnish resistance $R_{n}$.

The resultant value of contact resistance (transition) is equal to:

$$
R_{z}=R_{k}+R_{n}
$$

The tarnish resistance $R_{n}$ is difficult to determine analytically, since it depends on multiple, sometimes random, factors including: temperature, humidity, contact material. The shape resistance $R_{k}$ mainly depends on the resistivity and hardness of the contact material. To its description the single-point model with elliptical, equipotential current flowlines is often used $[5,7]$. The actual contact area is much smaller than the apparent (nominal) surface of the contact point. This model can be considered correct, at low contact pressure forces used in relays.

The value of the contact resistance is affected by the material used for the contact rivet. As used may be the contact points of pure metals, including copper, silver, gold, platinum, palladium, tungsten or molybdenum. More often alloys and sinters, such as silver-copper, silver-cadmium, silver-palladium, silver-cadmium oxide, silvertungsten, silver-nickel, silver-tin oxide are used [3]. Contacts may be

(*) Tekst artykułu w polskiej wersji językowej dostępny w elektronicznym wydaniu kwartalnika na stronie www.ein.org.pl 
covered with an additional layer of material with the aim of improving their certain properties (eg. resistance to material migration). Tin, silver or gold coverages are used. Coverage of the contact with the tin layer leads to a slight increase of the contact resistance relative to the uncoated material. Silver layer has the opposite effect, it reduces the contact resistance transition [19]. At present the most widely usedcontact materials, in medium power low-voltage AC relays are sinters of silver with: nickel $\mathrm{AgNi}$, cadmium oxide $\mathrm{AgCdO}$ and tin oxide $\mathrm{AgSnO}_{2}$. The properties of each materials are as follows [3, 23]:

- AgNi: exhibits a low material migration, is not resistant to the influence of sulfur and its compounds and is prone to oxides formation,

- $A g C d O$ : sulfur-sensitive material, characterized by resistance to welding, its application promotes the process of the electric arc extinguishing, is also resistant to material migration,

- $\mathrm{AgSnO}_{2}$ : the material is characterized by high thermal stability and material migration resistance, characterized by a stable contact resistance transition.

Materials made as silver-metal or silver-metal oxide are generally having a high resistance to welding [21]. The frequency and strength of welding during switching increases proportionately to the value of switching current arc, while the arc burning time has no such influence [17]. The force of contact welding does not exhibit the dependence on the static contact pressure force. It is however dependent on the speed of movement of the movable contact. These considerations are valid primarily for contacts made of pure silver [17].

\section{Testing set}

Miniature relays, using two previously mentioned contact materials, that is, $\mathrm{AgNi}$ and $\mathrm{AgSnO}$, were subjected to research. For the later one two types of contacts, full and bimetal, have been tested. Bimetallic rivets are usually made by powder metallurgy technology or in the case of using metal oxides internal oxidation. Full rivets are often produced from the wire made of the contact material and their shape is obtained in the process of cold forging treatment. Electrical diagram of the testing set is shown in figure 1 . The system is powered directly from the low voltage power network $230 \mathrm{~V}_{\mathrm{AC}}$. The circuit is protected against short circuits and overloads by circuit breakers with a rated operational current $16 \mathrm{~A}$ and $\mathrm{B}, \mathrm{C}$ and $\mathrm{D}$ characteristic, and a general purpose fuse $\mathrm{gG} 16$. For each protection device a single switching

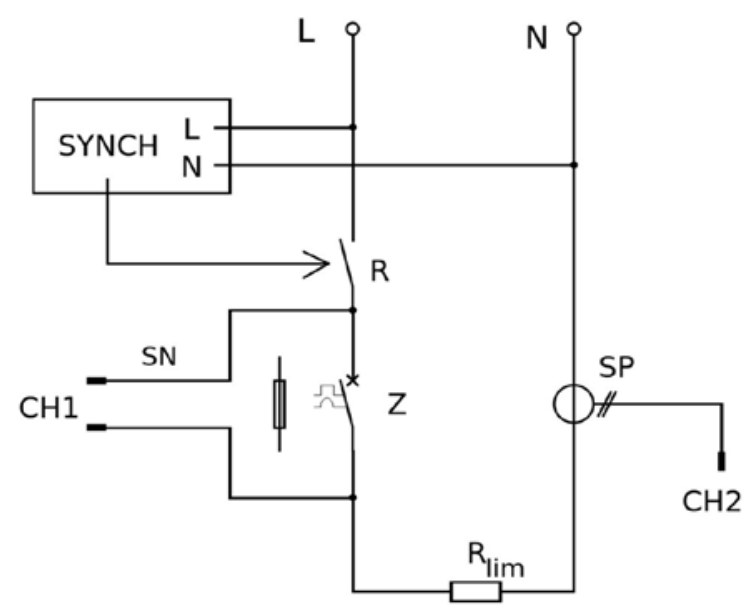

Fig. 1. Testing set electrical diagram: $R$-tested relay, $Z$-circuit protection: circuit breaker or fuse, $R_{\text {lim }}$ - limiting resistor, $S Y N C H$ - synchronizing device, $\mathrm{SP}$ - current probe, $\mathrm{SN}$ - voltage probe, $\mathrm{CH} 1$, $\mathrm{CH} 2$ - oscilloscope channels attempt with each of said contact material was made. By using the synchronizing device the moment of relay switching with the selected voltage phase repeatable testing conditions were obtained. As phase switching the zero crossing voltage was selected. Expected short circuit current was limited by resistor to the value of $320 \mathrm{~A}\left(I_{m}=453 \mathrm{~A}\right)$. The average value of short circuit current peak for all samples was $413 \mathrm{~A}$. The value lower than the expected may results from limiting it by the circuit protection device.

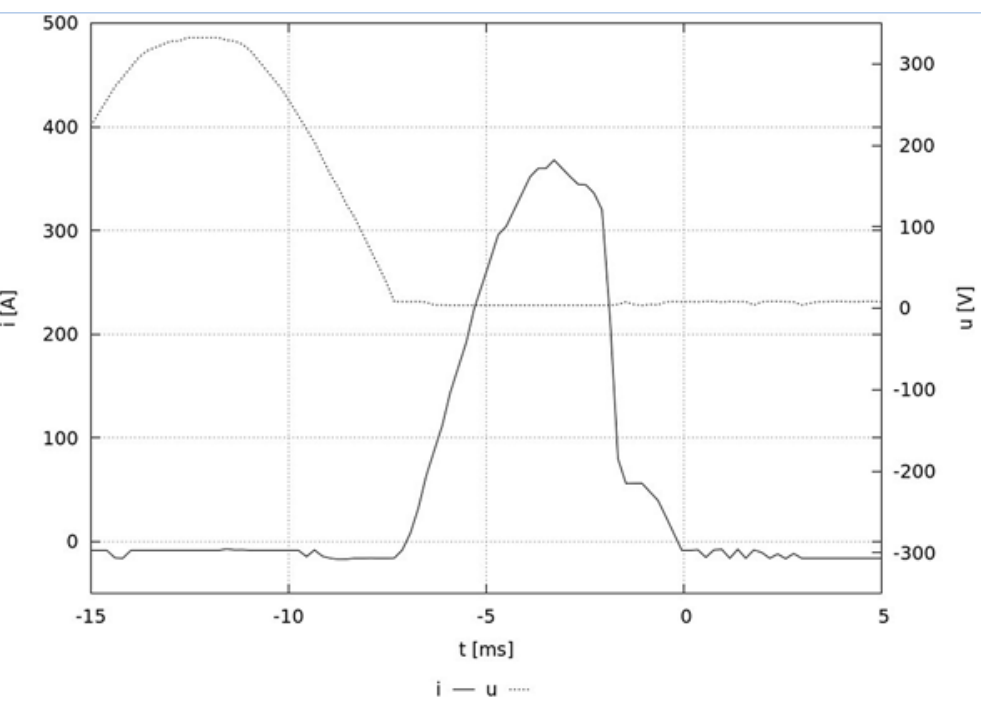

Fig. 2. The oscillogram of current intensity in the test circuit and voltage between contacts of the relay for randomly selected sample

The course of current intensity and voltage between rivets were recorded by oscilloscope using current and voltage probes. An exemplary oscillogram is shown in the figure 2 . Relays were connected to the set through a dedicated switching slot. Resistance measurement was performed with four-wire Kelvin method using low resistance meter MI3252 by Metrel. For obtained results taken into account the resistance of the current paths transition of socket and relay was applied, to determine the value of searched contact resistance as closes as possible.

\section{The results of measurements}

Three types of relays with contacts made of the previously mentioned materials were tested. Each of them has been subjected to one switching trial. Before and after the circuit current switching test the transition resistance was measured. Attempts were performed in two ways, for relays both conditioned and not conditioned. As conditioning the author understands the mechanical processing of contacts by making a specified number of cycles (performed without electrical load). Conditioning of contacts affects the initial value of contact resistance [11]. The number of cycles for conditioning operations amounted to two thousand. For such number of cycles the contact resistance stabilization succeeded, and the differences between consecutive measurements showed little fluctuations. The tests were performed for various commonly used, overcurrent protections. Based on these results an attempt to demonstrate whether there is an additional factor that could affect the outcome was made. Average values of contact resistance for these cases, divided into relays subjected to conditioning and nonconditioned, are shown in table 1 . These results do not distinguish between contact resistance values of the applied protection device because there was no such relationship in the applied test.

Changing the value of contact resistance for relays both conditioned and non-conditioned, depending on the contact material, for all tests carried out, is shown in figures 3 and 4 . Contact resistance for 
two cases after conditioning increased. Only for the AgNi there was a decrease of this value. This may be due to the fact that the material is characterized by the lowest value of the hardness in comparison to other (Tab. 2). Changing the structure of the contact point during switching operations, because of mechanical impact of the movable contact on the stationary one, might be possible due to the lower hardness of the material of the contact. This leads to increase of the actual contact surface area and thereby reduce the contact resistance. In other cases the opposite effect, that are loadless switching operations lead to an increase in contact resistance, was observed. Area of surface deformation of the contact point is dependent on the resistance of the material for welding. The smaller the resistance the greater the contact surface is changed [22]. The working hypothesis to explain the relationship is as follows. Unused contact point is characterized by a certain irregular surface on which micro elevations appear. These micro-elevations, upon first linking may increase the number of contact points, leading to a reduction of contact resistance. During the conditioning the contact surface of the contact point changes by mechanically removing of micro-elevations. After this operation, the surface of the contact point reaches the correct for itself target shape, for which a fair thesis becomes the single point of contact. Along with the change of the surface of the contact point changes its tarnish layer. Because the time between individual stages of research (conditioning - measurement of resistance - switching test - measurement of resistance) was as short as possible, the impact of the tarnish layers on the final result was marginal.

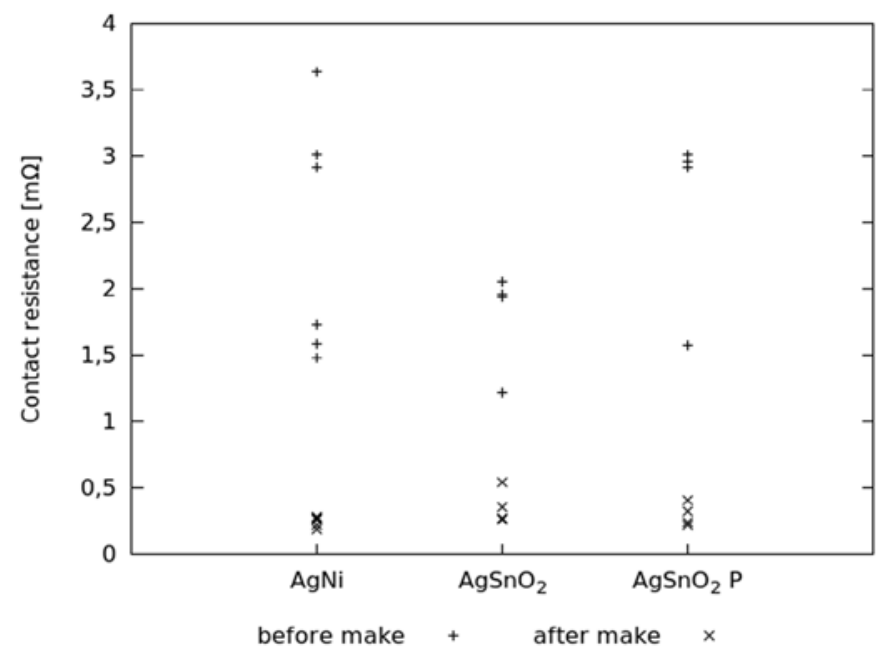

Fig. 3. Change of the contact resistance under the influence of switching the short circuit current; non-conditioned relays: $P$ - relay with full rivets

Table 1. Average values of the conditioned and non-conditioned relays contact resistance, before and after the short circuit switch test was performed,

\begin{tabular}{|c|c|c|c|}
\hline No. & Contact material & $\begin{array}{l}\text { The average value of the contact } \\
\text { resistance before test }\end{array}$ & $\begin{array}{c}\text { The average value of the contact } \\
\text { resistance after test }\end{array}$ \\
\hline & & {$[\mathrm{m} \Omega]$} & {$[\mathrm{m} \Omega]$} \\
\hline \multicolumn{4}{|c|}{ Non-conditioned relays } \\
\hline 1 & $\mathrm{AgNi}$ & 2,3927 & 0,2502 \\
\hline 2 & $\mathrm{AgSnO}_{2}$ & 1,7909 & 0,1262 \\
\hline 3 & $\mathrm{AgSnO}_{2} \mathrm{P}$ & 2,6162 & 0,3014 \\
\hline \multicolumn{4}{|c|}{ Conditioned relays } \\
\hline 1 & $\mathrm{AgNi}$ & 0,6252 & 0,3850 \\
\hline 2 & $\mathrm{AgSnO}_{2}$ & 6,4300 & 0,4040 \\
\hline 3 & $\mathrm{AgSnO}_{2} \mathrm{P}$ & 8,6381 & 0,2467 \\
\hline \multicolumn{4}{|c|}{$\mathrm{P}-$ relay with full rivets } \\
\hline
\end{tabular}
[4].

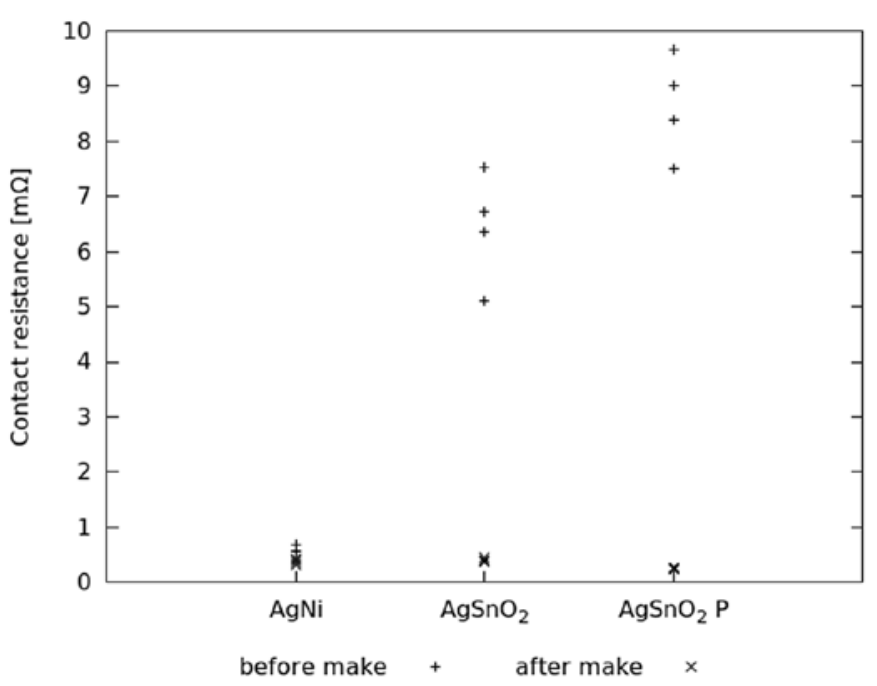

Fig. 4. Change of the contact resistance under the influence of switching the short circuit current; conditioned relays: $P$ - relay with full rivets

Table 2. Selected properties of contact materials used in low-voltage relays [20]

\begin{tabular}{|c|c|c|c|c|}
\hline \multirow{2}{*}{ Material } & Density & Hardness & Thermal conductivity at $20^{\circ} \mathrm{C}$ & Electrical conductivity \\
\cline { 2 - 5 } & {$\left[\mathrm{kg} / \mathrm{m}^{3}\right]$} & {$[\mathrm{HB}]$} & {$[\mathrm{W} / \mathrm{K} \cdot \mathrm{m}]$} & $10^{-8}[\Omega \mathrm{m}]$ \\
\hline $\mathrm{AgNi}$ & 10300 & 50 & 350 & 1,84 \\
\hline $\mathrm{AgSnO}_{2} / \mathrm{AgSnO}_{2} \mathrm{P}$ & 9900 & 70 & 307 & 2,04 \\
\hline
\end{tabular}

From Table 1 it also follows that regardless of the initial value of the contact resistance, after attempting to switch short-circuit current, the resistance significantly decreases.

When switching the short circuit current the pre-ignition arc or contact bounce during the conduction of electricity may occur. The fact which phenomenon occurs contributes to contacts welding force

Both of these phenomena affect very negatively on the condition of the contact point and lead to the appearance of the electric arc. With the increase in the value of the switching current intensity increases the loss of mass of the contact point $[2,18,21]$. In addition, the arc can lead to a strong local heating of the arc spot, even above the melting point of the contact material [12]. If at least on the surface of one of the contact points the contact material will be melted and at the same time after contact occurs, there will be welding of contacts [13]. Original contact materials' properties change when the contact area or composition of the material changes [22]. The composition can be altered by the thermal influence of current. These relationships are correct primarily for connecting currents with considerable intensity, on the order of several kilo amperes.

\section{Summary}

The occurrence of the short circuit current in the electrical installation is most often the result of an emergency and as such is a unconsolidated event. Based on the results of measurements it can be seen that the short circuit current switching via relay significantly affects the value of its contact resistance. For each of the registered cases there was a decrease of contact resistance values. Its low value can be considered decent, if only because of lower power losses and lower temperature rise of the contact point of the relay during normal use. Conditioning of contacts is substantially affecting the contact resistance. You can not clearly determine whether this operation will result in its increase or decrease. For contacts made of AgNi there was a decrease of this 
value, whereas for both contacts performed of $\mathrm{AgSnO}_{2}$ it increased significantly. Regardless of the initial value of contact resistance after the short circuit current switching test this resistance was significantly decreased. Knowledge of contact resistance value under normal operating conditions could be used to indirectly assess the state the contacts surface. In further studies it is expected to develop methods for assessing the state of wear of the surface on the basis of the change in contact resistance.
The research is funded under purpose subsidy for scientific research or development works and the tasks associated with it, for the development of young scientists and doctoral students at the Faculty of Electrical Engineering Poznan University of Technology No. 04/41/ DSMK/4133.

\section{References}

1. Borkowski P. Arc erosion of contacts on switching high currents. Archives of Electrical Engineering 2004; 53: 259-287.

2. Borkowski P. Nowoczesne metody badań zestyków elektrycznych. Akademicka Oficyna Wydawnicza EXIT, 2013.

3. Celiński Z. Materiałoznawstwo elektrotechniczne. Oficyna Wydawnicza Politechniki Warszawskiej, 2011.

4. Chen Z.K, Witter G.J. A Study of Dynamic Welding of Electrical Contacts with Emphasis on the Effects of Oxide Contentfor Silver Tin Indium Oxide Contacts. Proceedings of the 56th IEEE Holm Conference on Electrical Contacts 2010; 56: 1-6.

5. Ciok Z. Procesy Łączeniowe w układach elektroenergetycznych. Wydawnictwo Naukowo-Techniczne 1983.

6. Doublet L, Ben Jemaa N, Hauner F, Jeannot D. Make arc erosion and welding tendency under 42 VDC in automotive area. Proceedings of the Forty-Ninth IEEE Holm Conference on Electrical Contacts; 2003:158-162.

7. Holm R. Electric Contacts. Springer-Verlag Berlin Heidelberg GmbH 1981

8. Kharin S.N, Sarsengeldin M. Influence of Contact Materials on Phenomena in a Short Electrical Arc. Key Engineering Materials 2012; 510511: 321-329, http://dx.doi.org/10.4028/www.scientific.net/KEM.510-511.321.

9. Kolimas Ł. Analysis of the making arcing time during current switching. Przeglad Elektrotechniczny 2008; 84: 72-74.

10. Kolimas Ł. Modelowanie i analiza rozpływu temperatury w torach wielkoprądowych i zestykach. Przegląd Elektrotechniczny 2014; 9: $183-186$.

11. Książkiewicz A. Change of electric contact resistance of an electromagnetic relay during switching operations withoutelectric load. 5th International Interdisciplinary Technical Conference of Young Scientists InterTech 2012; 5: 257-260

12. Książkiewicz A, Janiszewski J. Electrical contact temperature change after short-circuit current. Poznan University of Technology Academic Journals. Electrical Engineering 2014; 78: 65-70.

13. Książkiewicz A, Janiszewski J, Batura R. Influence of short-circuit AC currents on electrical contact resistance of low voltage relays. Poznan University of Technology Academic Journals. Electrical Engineering 2012; 70: 99-103.

14. Kulas S. Tory prądowe i układy zestykowe. Oficyna Wydawnicza Politechniki Warszawskiej 2008.

15. Maksymiuk J, Pochanke Z. Obliczenia i badania diagnostyczne aparatury rozdzielczej. Wydawnictwo Naukowo-Techniczne, 2001.

16. Morin L, Jemaa N.B, Jeannot D. Make arc erosion and welding in the automotive area, IEEE Transactions on Components and Packaging Technologies 2000; 23: 240-246, http://dx.doi.org/10.1109/6144.846760

17. Neuhaus A.R, Rieder W.F, Hammerschmidt M. Influence of Electrical and Mechanical Parameters on Contact Welding in Low Power Switches. IEEE Transactions on Components and Packaging Technologies 2004; 27: 4-11, http://dx.doi.org/10.1109/TCAPT.2004.825777.

18. Pons F, Cherkaoui M. An electrical arc erosion model valid for high current: Vaporization and Splash Erosion. Proceedings of the 54th IEEE Holm Conference on Electrical Contacts 2008; 54: 9-14, http://dx.doi.org/10.1109/holm.2008.ecp.15.

19. Sawada S, Shimizu K, Hattori Y, Tamai T, Iida K. Analysis of Contact Resistance Behavior for Electric Contacts with Plating Layer. Proceedings of the 56th IEEE Holm Conferenceon Electrical Contacts 2010; 56: 1-8, http://dx.doi.org/10.1109/holm.2010.5619560.

20. Thurston M. O. Electrical Contacts. Fundamentals, Applications and Technology. Taylor \& Francis Group LLC, 2007.

21. Walczuk E, Borkowski P, Księżarek S, Missol W, Rdzawski Z, Durst K. Evaluation of Basic Electrical Parameters of Silver-Based Contact Materials of Different Chemical Composition and Manufacturing Technology. Proceedings of the 56th IEEE Holm Conference on Electrical Contacts 2010; 56: 1-8, http://dx.doi.org/10.1109/holm.2010.5619550.

22. Zhenbiao L, Lichun C, Jiyan Z. The metallurgical researchon contact surface deterioration of AgNi, AgW, AgFe, AgCu contact materials. Proceedings of the Forty-First IEEE HolmConference on Electrical Contacts 1995; 41: 346-349.

23. www.relpol.com.pl, 2014. Relpol. Przekaźniki.

\author{
Andrzej KSIĄŻKIEWICZ \\ Jerzy JANISZEWSKI \\ Faculty of Electrical Engineering \\ Poznan University of Technology \\ Piotrowo 3a, 60-965 Poznan, Poland \\ E-mail: andrzej.ksiazkiewicz@put.poznan.pl, \\ jerzy.janiszewski@put.poznan.pl
}

